Solihin, M. $\cdot$ A.N. Putri $\cdot$ A. Setiawan $\cdot$ D. Siliwangi $\cdot$ M. Arifin

\title{
Karakteristik indeks vegetasi pada berbagai penggunaan lahan di hulu Sub Das Cikapundung melalui interpretasi citra satelit Landsat 8
}

\begin{abstract}
Sari Perubahan penggunaan lahan di hulu Sub DAS dapat berdampak pada kondisi DAS secara keseluruhan. Pemantauan kondisi eksisting perubahan penggunaan lahan diperlukan. Salah satu cara untuk memantau kondisi penggunaan lahan yaitu melalui monitoring indeks vegetasinya. Penelitian ini bertujuan untuk melihat karakteristik indeks vegetasi pada penggunaan lahan di sebagian Hulu Sub DAS Cikapundung. Lokasi studi terletak di Desa Cikole, Cikidang, Cibodas, Wangunharja, dan Suntenjaya di Kecamatan Lembang. Penelitian ini dilakukan melalui interpretasi citra satelit landsat 8. Metode analisis yang digunakan berupa transformasi indeks vegetasi menggunakan NDVI untuk merepresentasikan tingkat kehijauan dan kerapatan vegetasi pada lokasi studi. Hasil analisis menunjukkan karakteristik NDVI yang berbeda pada setiap jenis penggunaan lahan. Nilai NDVI pada lokasi studi berkisar antara $(-0,228426)-0,461794$. Tingkat kehijauan vegetasi di lokasi studi dominan pada tingkat kehijauan rendah dan kerapatan vegetasi dominan pada kerapatan jarang. Keragaman karakteristik penggunaan lahan di lokasi studi dipengaruhi oleh adanya variasi jenis vegetasi, sebaran vegetasi, dan jenis material objek. Perlu pengelolaan penggunaan lahan yang tepat untuk meningkatkan peran ekologis kawasan sekaligus mengurangi erosi dan aliran permukaan di hulu sub DAS Cikapundung.
\end{abstract}

Kata kunci: Cikapundung · DAS · Indeks vegetasi · Landsat $8 \cdot$ Penggunaan lahan

\section{Characteristics of vegetation index on various land uses in the upstream of cikapundung watershed by landsat 8 satellite imagery interpretation}

\begin{abstract}
Land use changes in the upper watershed have an impact on the overall condition of the watershed. Monitoring existing conditions of land use change is needed. One way to monitor the land use condition is through monitoring the vegetation index. This study aimed to identify characteristics of vegetation index on various land uses in the upstream of the Cikapundung watershed. The study sites were located in Cikole, Cikidang, Cibodas, Wangunharja, and Suntenjaya of Lembang District. The resereach was done using Landsat 8 satellite imagery interpretation The analytical methods were used the transformation of vegetation index using NDVI to represent the level of greenness and density of vegetation at the study site. The results of the analysis shown that characteristics of the vegetation index were different for each type of land use. NDVI values had ranged from $(-0,228426)-$ 0,461794 . The greenness vegetation level was dominant at low greenness, while dominant vegetation density was spare. The diversity of land use characteristics were influenced by variations in vegetation types, vegetation distribution, and material types of objects. Appropriate land use management is needed to enhance the ecological role of the area as well as reducing erosion and surface runoff in the Cikapundung sub-watershed.
\end{abstract}

Keywords : Cikapundung · Land use $\cdot$ Landsat $8 \cdot$ Vegetation index $\cdot$ Watershed

Diterima : 16 April 2020, Disetujui : 11 Desember 2020, Dipublikasikan : 31 Desember 2020 doi: https://doi.org/10.24198/kultivasi.v19i3.28625

Solihin, M. · A.N. Putri · A. Setiawan · D. Siliwangi · M. Arifin

Program Studi Agroteknologi Fakultas Pertanian, Universitas Padjadjaran

Korespondensi : $\underline{\text { m.amir.solihin@unpad.ac.id }}$ 


\section{Pendahuluan}

Sutrisna et al. (2010) mengungkapkan sub DAS Cikapundung berada di hulu DAS Citarum memiliki lahan yang relatif subur karena berkembang dari bahan induk vulkanik. Selain terdapat penggunaan lahan hutan dan perkebunan. di sub DAS Cikapundung juga terdapat lahan pertanian dengan komoditas bernilai ekonomi tinggi, terutama sayur-sayuran, sehingga menjadi salah satu sentra produksi sayuran di Jawa Barat. Penggunaan lahan pada sub DAS Cikapundung tersebut perlu memperhatikan karakteristik lahan dan fungsi lahan di hulu Sub DAS sebagai area tangkapan air.

Perubahan penggunaan lahan terjadi di berbagai wilayah, salah satunya di Daerah Aliran Sungai (DAS) Citarum. Tutupan lahan di Citarum sudah mencapai $15,96 \%$ dan di bagian Hulu DAS hanya sebesar 4,94\% sehingga berpengaruh terhadap karakteristik hidrologi DAS (Salim et al., 2019). Hal ini berpengaruh pada penurunan kemampuan menahan air di hulu DAS dan mengendalikan erosi serta aliran permukaan. Salah satu bagian dari DAS Citarum yang banyak mengalami perubahan penggunaan lahan adalah Sub DAS Cikapundung bagian Hulu. Berdasarkan data penggunaan Lahan tahun 2014 di Hulu Sub DAS Citarum menunjukkan 10,446\% hutan dan $16,76 \%$ perkebunan (Dinas Lingkungan Hidup Jabar, 2018). Hal ini menunjukkan luasan yang kurang ideal bagi fungsi hidrologis Hulu Sub DAS Cikapundung.

Perubahan penggunaan lahan di kawasan Hulu Sub DAS Cikapundung berdampak pada kondisi hidrologi di wilayah tersebut (Nurrochman, 2018). Berkurangnya tutupan lahan vegetasi akan mempengaruhi pola hidrologis dalam DAS secara menyeluruh, seperti berkurangnya hambatan limpasan permukaan dan cepatnya air mengalir menuju sungai utama akibat hilangnya vegetasi dan serasah hutan. Oleh karena itu, keberadaan vegetasi dapat mempengaruhi hasil aliran keluar harus dipertimbangkan dalam pengelolaan DAS (Latuamury, 2012).

Tutupan lahan erat kaitannya dengan penggunaan sumber daya alam oleh manusia yang terjadi di suatu bidang lahan tersebut. Adanya peningkatan aktivitas manusia memungkinkan cepatnya perubahan penggunaan lahan. Perubahan penggunaan lahan dapat dianalisis menggunakan gambaran sebaran kerapatan vegetasi (Irawan, 2017). Kinthada et al. (2014), Zhao et al. (2017), dan Hidayati et al. (2018) mengungkapkan bahwa pada penggunaan lahan yang berbeda memiliki karakteristik sebaran vegetasi berlainan seiring nilai indeks vegetasiyang berbeda..

Kondisi tutupan lahan bervegetasi dapat diketahui diantaranya melalui metode vegetation index (Latuamury dkk, 2012), point centered quarter (Munawwaroh, 2016), line transect (Arista, 2017), ataupun quadrat sampling (Pertiwi, 2019). . Penelitian ini menggunakan metode indeks vegetasi sebagai pengukuran kuantitatif yang merepresentasikan tingkat kehijauan dan kerapatan vegetasi. Latuamury dkk. (2012) mengungkapkan indeks vegetasi cukup efektif untuk menggambarkan kerapatan vegetasi. Lebih lanjut dikemukakan dari hasil penelitian terkait $55-60 \%$ nilai spektral dapat menjelaskan tingkat kerapatan tajuk tanaman sedangkan 40$45 \%$ sisanya dipengaruhi oleh faktor lain.

Vegetasi akan menyerap cahaya merah oleh klorofil kemudian memantulkan cahaya inframerah dekat oleh jaringan mesofil (Sudiana dan Diasmara, 2008). Indeks vegetasi merupakan rasio antara pantulan (refleksi) gelombang red (merah) dan near infrared (NIR). Sudiana dan Diasmara (2008) menyebutkan Indeks vegetasi pada daratan non-vegetasi (perairan, pemukiman, tanah kosong terbuka, dan wilayah dengan kondisi vegetasi rusak) akan menunjukan nilai rasio yang rendah (minimum), sedangkan pada wilayah dengan vegetasi rapat dan kondisi sehat maka nilai rasio akan sangat tinggi (maksimum). Namun, karena nilai rasio tersebut dapat memberikan nilai yang sangat besar untuk tumbuhan yang sehat maka dikembangkan berbagai algoritma dalam metode indeks vegetasi ini.

Variasi lain dari indeks vegetasi diantaranya NDVI (Normalized Difference Vegetation Index), RVI (Ratio Vegetation Index), TVI (Transformed Vegetation Index), PVI (Perpendicular Vegetation Index), SAVI (Soil Adjusted Vegetation Index), dan EVI (Enhanced Vegetation Index) (Tucker, 1979; Sudiana et al., 2008; Frananda et al., 2015; Lintang et al., 2017). Nilai indeks vegetasi tersebut akan bervariasi tergantung pada algoritma transformasi yang digunakan. Namun para peneliti menyetujui NDVI sebagai metode yang paling efisien dan matriks simpel yang dapat mengidentifikasi area bervegetasi dengan kondisi berbeda (Tucker, 1979). 
Berdasarkan hasil penelitian Lintang (2017), akurasi terbaik adalah dengan NDVI dengan akurasi tertinggi terdapat pada klasifikasi transformasi NDVI sebesar 75,61\% sedangkan akurasi terendah ada pada klasifikasi transformasi RVI. Selain itu, band red dan band NIR dapat membedakan vegetasi dan nonvegetasi secara jelas. Untuk itu penggunaan NDVI dapat digunakan sebagai pilihan utama sebagai pendekatan indeks vegetasi.

Terkait dengan identifikasi kondisi tutupan lahan di hulu Sub DAS Cikapundung, Informasi penggunaan lahan dan pengukuran nilai NDVI di Kecamatan Lembang dapat dipermudah dengan penggunaan teknologi SIG (Sistem Informasi Geografis). Interpretasi objek permukaan bumi dari citra satelit dapat dilakukan dengan beberapa metode diantaranya supervised classification, unsupervised classification, rule-based classification (Navulur, 2007).

Citra satelit yang dapat digunakan memiliki resolusi tinggi sampai rendah, tergantung pada kombinasi band yang digunakan, luas area studi yang dikaji dan kemudahan akses data. Suwargana (2013) menyebutkan terdapat tiga tingkat ukuran resolusi spasial yaitu tinggi $(0,6-4 \mathrm{~m}$; seperti WorldView, Ikonos), menengah (4-30 m; seperti Landsat, SPOT), dan rendah (30->1000 m; seperti MODIS, NOAA).

Upaya pemantau tutupan lahan khususnya di kawasan hulu DAS maupun sub DAS, dapat dilakukan melalui interpretasi citra satelit. Klasifikasi penggunaan lahan tersebut didasarkan pada kunci interpetasi citra yaitu warna/rona, bentuk, ukuran, pola, bayangan, tekstur, situs, dan asosiasi (Sutanto, 1986). Salah satu citra yang umum digunakan para peneliti untuk interpretasi penggunaan lahan yaitu Citra Landsat 8. Hasil klasifikasi penggunaan lahan ini dapat menjadi informasi penting melengkapi kondisi tutupan lahan melalui indeks vegetasi di hulu Sub DAS Cikapundung.

Interpretasi sebaran vegetasi yang ditunjukkan dari nilai NDVI dapat menggunakan citra yang memiliki band NIR dan red. Citra yang dapat digunakan diantaranya NOAA AVHRR (Sandholt et al., 2002; Sudiana \& Diasmara, 2008), Terra MODIS (Sudiana \& Diasmara, 2008), WorldView (Hidayati et al., 2017; Hogrefe, 2017), dan Landsat 8 (Lintang et al., 2017; Kurniawan et al., 2017; Feng et al., 2019).. Citra yang paling banyak digunakan untuk penentukan indeks vegetasi yaitu citra Landsat 8 .

Penelitian ini mengidentifikasi karakteristik vegetasi pada berbagai penggunaan lahan di lokasi studi melalui nilai NDVI. Nilai NDVI merepresentasikan tingkat kehijauan dan kerapatan tajuk vegetasi.

\section{Bahan dan Metode}

Lokasi penelitian termasuk wilayah Hulu Sub DAS Cikapundung, khususnya sebagian berada di Kecamatan Lembang yaitu Desa Cikole, Cikidang, Cibodas, Wangunharja, dan Suntenjaya. Penentuan lokasi ini berkaitan dengan sumber citra yang diperoleh pada lokasi tersebut, dimana terdapat tutupan awan paling kecil diantara citra lainnya.

Pengolahan dan analisis data dilakukan di Laboratorium Survey Pemetaan dan Evaluasi Lahan, Departemen Ilmu Tanah dan Sumberdaya Lahan, Fakultas Pertanian Universitas Padjadjaran, Kecamatan Jatinangor, Kabupaten Sumedang, Provinsi Jawa Barat.

Bahan. Citra Landsat 8 hasil perekaman pada 22 Mei 2019 dengan pertimbangan waktu yang termasuk musim hujan, Peta Rupa Bumi Indonesia Kabupaten Bandung Barat 1: 25.000, image Google Earth

Pra Pengolahan Citra. Sebelum dilakukan analisis, pengolahan citra dilakukansebagai berikut: koreksi geometri, koreksi radiometrik, cloud masking, dan pemotongan citra pada lokasi studi. Koreksi geometrik dilakukan untuk mendapatkan nilai RMSE <0,5 (Jaya, 2010). Koreksi radiometrik dilakukan melalui metode histogram equalization. Untuk memisahkan area yang tertutup awan diidentifikasi dengan band 9 (Cirrus) menggunakan tool highlight cloud..Setelah diperoleh citra sesuai lokasi studi, selanjutnya dilakukan perhitungan nilai NDVI melalui kombinasi band 5 dan 4 . .

Penggunaan lahan. Peta penggunaan lahan di Kecamatan Lembang diperoleh dari peta penggunaan lahan Kecamatan Lembang Tahun 2017. Peta tersebut selanjutnya diperbaharui dengan peta citra hasil analisis klasifikasi penggunaan lahan terbimbing dengan menggunakan band 4 (red), 3 (green), dan 2 (blue), dan dipertajam untuk memperjelas objek dengan menggunakan band 8 (panchromatic) melalui ErMapper. 
Pengolahan Citra. Analisis citra bertujuan untuk menentukan nilai NDVI. Nilai NDVI tersebut selanjutnya diklasifikasikan ke dalam klasifikasi tingkat kehijauan dan kerapatan vegetasi dengan mengacu pada Peraturan Menteri Kehutanan Republik Indonesia (2012). Analisis NDVI dengan menggunakan citra Landsat 8 dengan Rumus sebagai berikut : NDVI $=\frac{\text { NIR }- \text { Red }}{\text { NIR+Red }}$

Keterangan :

NDVI : Normalized Difference Vegetation Index

NIR : Band 5 (inframerah dekat)

Red : Band 4 (merah)

Penyajian Peta. Sebaran penggunaan lahan, tingkat kehijauan vegetasi, dan tingkat kerapatan tajuk vegetasi di lokasi studi selanjutnya ditampilkan dalam bentuk Peta.Klasifikasi penggunaan lahan dilokasi studi diantaranya hutan, perkebunan, tegalan/ladang, sawah irigasi, sawah tadah hujan, semak belukar, tanah terbuka, lahan terbangun dan permukiman.

Klasifikasi tingkat kehijauan (Tabel 1) dan kelas kerapatan tajuk (Tabel 2). Klasifikasi tersebut menunjukkan Semakin besar nilai NDVI maka tingkat kehijauan vegetasi dan kerapatan vegetasi semakin tinggi.

Tabel 1. Klasifikasi tingkat kehijauan.

\begin{tabular}{|c|c|c|}
\hline Kelas & Nilai NDVI & Keterangan \\
\hline 1 & $(-1)-(-0,03)$ & Tanpa vegetasi \\
\hline 2 & $(-0,03)-0,15$ & $\begin{array}{l}\text { Tingkat kehijauan sangat } \\
\text { rendah }\end{array}$ \\
\hline 3 & $0,15-0,25$ & Tingkat kehijauan rendah \\
\hline 4 & $0,25-0,35$ & Tingkat kehijauan sedang \\
\hline 5 & $0,36-1,00$ & Tingkat Kehijauan tinggi \\
\hline
\end{tabular}

Sumber: Peraturan Menteri Kehutanan Republik Indonesia (2012)

Tabel 2. Klasifikasi kerapatan tajuk.

\begin{tabular}{ll}
\hline Kelas & Nilai NDVI \\
\hline $\begin{array}{l}\text { Lebat }(\text { Kerapatan } \\
\text { tajuk }>70 \%)\end{array}$ & $0,36 \leq \mathrm{NDVI} \leq 1,00$ atau \\
Sedang (Kerapatan & $0,26 \leq \mathrm{NDVI} \leq 0,35$ \\
tajuk 50-70 \%) & \\
Jarang (Kerapatan & $-1,0 \leq \mathrm{NDVI} \leq 0,25$ \\
tajuk $<50 \%)$ &
\end{tabular}

Sumber: Peraturan Menteri Kehutanan Republik Indonesia (2012)
Analisis Statistik. Keragaman atau variasi pada setiap klasifikasi diketahui dari nilai standar deviasi. Keragaman data tinggi ditunjukkan oleh nilai standar deviasi yang tinggi. Standar deviasi dapat dihitung dengan rumus berikut (Soewarno, 1995):

$$
s_{x}=\sqrt{\frac{\sum_{i=1}^{n}\left(x_{i}-\bar{x}\right)^{2}}{n-1}}
$$

\section{Hasil dan Pembahasan}

Penggunaan Lahan. Peta penggunaan lahan (Gambar 1) digunakan untuk melihat karakteristik nilai NDVI pada berbagai penggunaan lahan di lokasi studi.

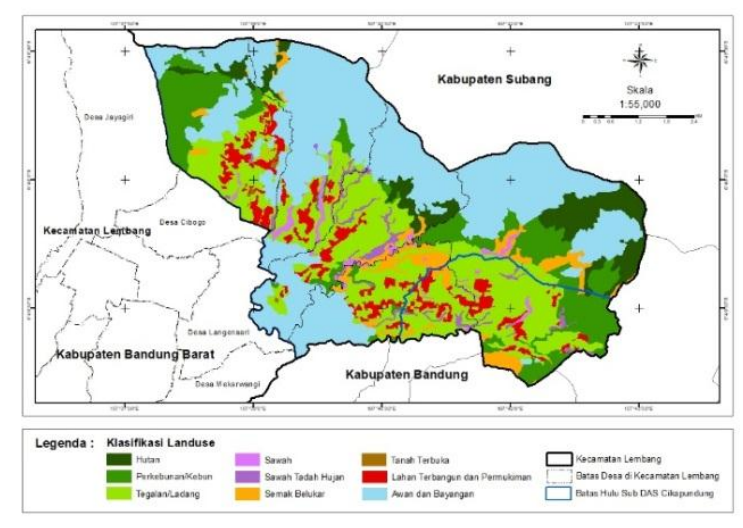

Gambar 1. Peta penggunaan lahan di lokasi studi

Persentase tutupan awan pada lokasi studi sebesar 23,88\% (1083,04 ha) dan jika ditambah bayangan awan menjadi 40,63\% (1842,95 ha). Ini karena citra Landsat 8 yang digunakan bertepatan dengan musim hujan sehingga terdapat awan dan bayangan yang cukup luas.

Tabel 3. Luasan Penggunaaan Lahan di Lokasi Studi

\begin{tabular}{lll}
\hline No & Penggunaan Lahan & Luasan (ha) \\
\hline 1 & Hutan & 305,74 \\
2 & Perkebunan & 638,08 \\
3 & Tegalan & 1162,60 \\
4 & Sawah & 73,77 \\
5 & Sawah Tadah Hujan & 83,48 \\
6 & Semak Belukar & 211,44 \\
7 & Tanah Terbuka & 4,89 \\
8 & Lahan Terbangun dan & 217,21 \\
& Permukiman & \\
\hline
\end{tabular}


Tabel 3 menunjukkan penggunaan lahan setelah dikurangi tutupan awan dan bayangannya. Penggunaan lahan dari yang terluas hingga tersempit sebagai berikut: tegalan dan ladang seluas 1162,6 ha $(25,63 \%)$, perkebunan/kebun seluas 638,08 ha $(14,07 \%)$, hutan seluas 305,74 ha $(6,74 \%)$, lahan terbangun dan permukiman seluas 217,21 ha $(4,79 \%)$, semak belukar seluas 211,44 ha $(4,66 \%)$, sawah tadah hujan seluas 83,48 ha $(1,84 \%)$ dan penggunaan lahan tanah terbuka seluas 4,89 ha $(0,11 \%)$.

Tutupan awan dan bayangannya mempengaruhi nilai NDVI karena memiliki efek hamburan yang sama pada semua panjang gelombang sehingga akan berwarna putih (Dewi dan Supianto, 2015). Nilai NDVI pada awan akan semakin rendah (mendekati 0 atau -1) karena spektral yang terpancarkan berwarna putih. Selain itu, bayangan dari awan juga akan mempengaruhi nilai radiasi yang terpancar oleh objek dan ditangkap satelit sehingga dapat mempengaruhi nilai NDVI. Puntodewo, et al. (2003) menyebutkan salah satu faktor yang mempengaruhi kualitas citra adalah pengaruh atmosferik terutama uap air, aerosol, dan ozon yang sangat mengganggu band sinar tampak dan band infrared. Oleh karena itu, pada penelitian ini awan dan bayangan digabungkan dalam satu kelas dan tidak diperhitungkan dalam analisis NDVI.

Sebaran nilai NDVI. Gambar 2 menunjukkan nilai NDVI di lokasi studi berkisar antara $(-0,228426$ hingga 0,461794. Warna kuning-merah menunjukkan nilai NDVI rendah, sedangkan warna hijau muda-hijau tua menunjukkan nilai NDVI tinggi. Lahan dengan tutupan non-vegetasi (bangunan, pemukiman, tanah terbuka, dan perairan) memiliki nilai NDVI rendah, sedangkan lahan bervegetasi yang sehat dan sangat rapat memiliki nilai NDVI tinggi.

Tingkat kehijauan dan kerapatan tajuk vegetasi. klasifikasi mengacu pada Peraturan Menteri Kehutanan tahun 2012 (Gambar 2 dan Tabel 4). Kelas kehijauan sangat rendah (NDVI $(-0,03)$ - 0,15) memiliki area yang terluas, sedangkan kelas kehijauan tinggi (NDVI 0,36 $1,00)$ memiliki luasan yang lebih rendah. Tingkat kehijauan tinggi dan kerapatan vegetasi sangat rapat menunjukkan penggunaan lahan hutan, kehijauan sedang sampai rendah menunjukkan lahan pertanian (perkebunan, ladang/tegalan, sawah) atau semak belukar, sedangkan lahan tanpa vegetasi berupa lahan terbangun atau tanah kosong.

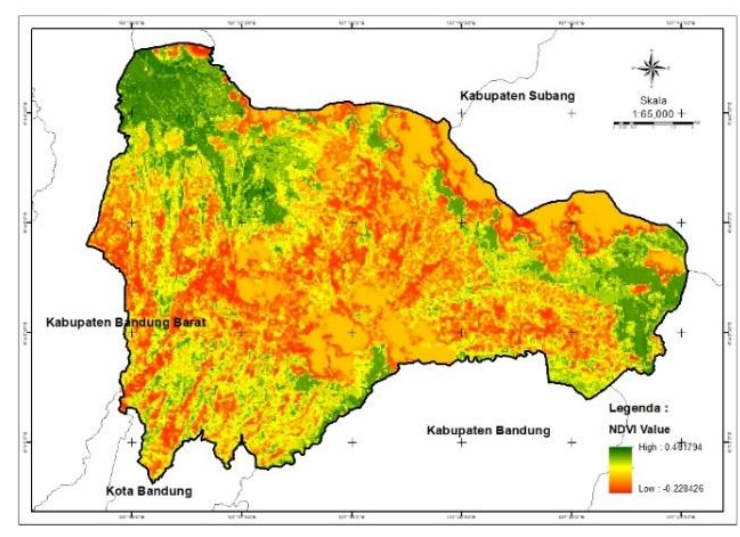

Gambar 2. Persebaran nilai NDVI di Kecamatan Lembang.

Tabel 4. Luasan area kelas tingkat kehijauan NDVI.

\begin{tabular}{lll}
\hline No & Klasifikasi NDVI & $\begin{array}{l}\text { Luasan } \\
\text { (ha) }\end{array}$ \\
\hline 1 & Tingkat Kehijauan Tinggi & 23,87 \\
2 & Tingkat Kehijauan Sedang & 280,69 \\
3 & Tingkat Kehijauan Rendah & 506,95 \\
4 & Tingkat Kehijauan Sangat & 978,92 \\
& Rendah & \\
5 & Lahan Tidak Bervegetasi & 894,06 \\
\hline
\end{tabular}

Luasnya lahan pada tingkat kehijauan rendah terkait dengan penggunaan lahan berupa tegalan dan ladang yang didominasi tanaman semusim, dan jarak tanam yang masih menyisakan lahan tanpa vegetasi.

Hutan dan perkebunan memiliki tingkat kehijauan tinggi sampai rendah, namun lebih dominan tingkat kehijauan rendah. Ini Sementara pada lahan perkebunan/kebun, semua jenis perkebunan digabung dalam satu klasifikasi perkebunan. Luasan hutan pada citra sebagian besar tertutupi awan yang tidak dianalisis pada penelitian ini sehingga menyisakan luasan yang rendah. Perbedaan jenis vegetasi, jarak tanam, dan kondisi tajuk pada kelas perkebunan menghasikan rata-rata tingkat kehijauan yang dominan rendah.

Lahan terbangun, permukiman, dan lahan tanpa vegetasi memiliki nilai NDVI pada tingkat kehijauan sangat rendah.. Hal ini disebabkan oleh sedikitnya sebaran vegetasi dan emisivitas radiasi merah dan near infrared pada material bangunan lebih rendah dibandingkan vegetasi. 


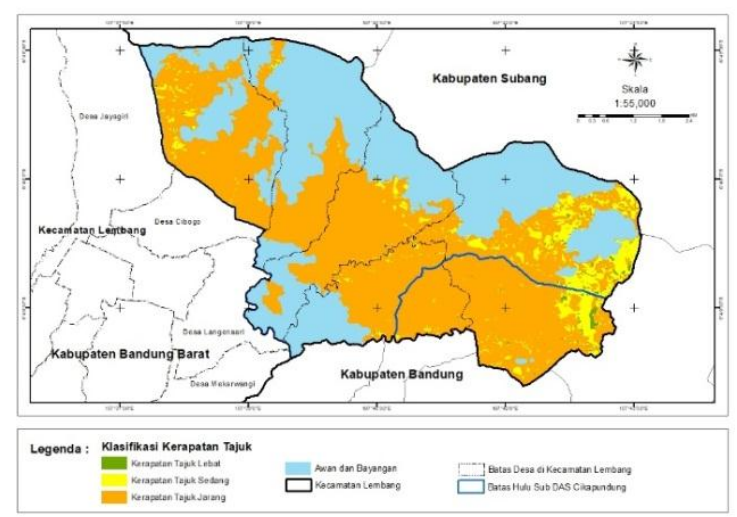

Gambar 3. Persebaran kerapatan tajuk vegetasi (NDVI) pada lokasi studi.

Gambar 3 menunjukkan persebaran kerapatan tajuk di lokasi penelitian. Kerapatan paling luas terdapat pada kelas kerapatan tajuk jarang dengan estimasi kerapatan tajuk $<50 \%$, sedangkan kelas kerapatan tajuk lebat memiliki luasan terendah. Kerapatan tajuk tanaman jarang dapat dipengaruhi oleh vegetasi yang ditanami dan latar tanah sehingga mempengaruhi nilai spektral. Variasi pantulan spektral dari kerapatan tajuk yang sama dapat disebabkan oleh perbedaan pada indeks luas daun (Purevdorj et al., 1998 dalam Latuamury et al., 2012). Faktor lain yang dapat mempengaruhi kerapatan tajuk yang dijelaskan dalam nilai spektral diantaranya kandungan klorofil, latar belakang tanah, dan pengaruh bayangan akibat aspek lereng.

Karakteristik NDVI pada Berbagai Penggunaan Lahan. Lahan pertanian di Kecamatan Lembang didominasi tegalan/ ladang dengan komoditas utama hortikultura diantaranya kol/kubis, sawi, wortel, cabe, tomat, dan lainnya. Tanaman hortikultura termasuk tanaman semusim, memiliki tinggi tanaman yang dominan rendah, dan jarak tanam yang kurang rapat (masih terdapat latar tanah) akan menghasilkan nilai NDVI yang termasuk dalam kelas tingkat kehijauan rendah sampai sangat rendah. Persebaran NDVI dapat dilihat pada Gambar 4.

Penggunaan lahan hutan (warna hijau tua) dan perkebunan (warna hijau muda) memiliki tingkat kehijauan tinggi sampai sedang (warna hijau tua-kuning) namun lebih dominan tingkat kehijauan sedang (warna kuning). Hal ini disebabkan sebagian besar hutan yang tertutup awan dan kondisi tajuk pada setiap jenis perkebunan yang berbeda sehingga dapat mempengaruhi nilai NDVI. Lahan terbangun atau permukiman memiliki NDVI yang termasuk pada kelas kehijauan sangat rendah sampai lahan tidak bervegetasi.

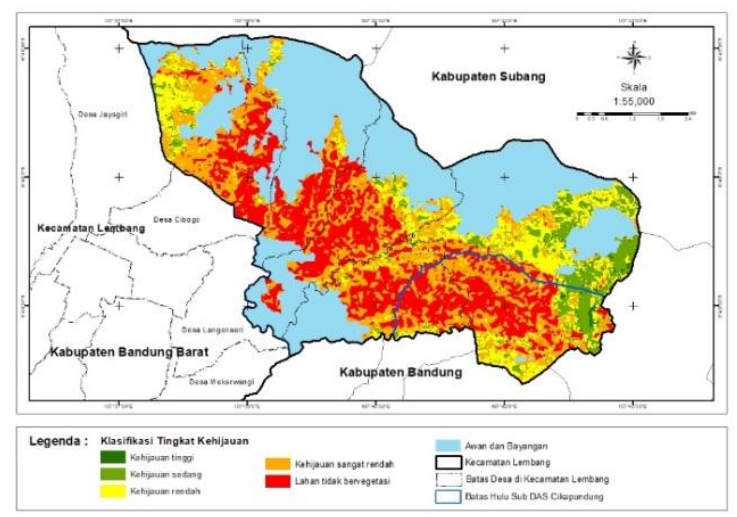

Gambar 4. Persebaran tingkat kehijauan vegetasi (NDVI) pada lokasi studi.

Tabel 5. Karakteristik NDVI terhadap penggunaan lahan.

\begin{tabular}{llll}
\hline No & Penggunaan Lahan & $\begin{array}{l}\text { Jumlah } \\
\text { Piksel }\end{array}$ & $\begin{array}{l}\text { Standar } \\
\text { Deviasi } \\
\text { NDVI }\end{array}$ \\
\hline 1 & Hutan & 3.391 & 0,106 \\
2 & Perkebunan & 7.063 & 0,113 \\
3 & Tegalan & 12.943 & 0,096 \\
4 & Sawah & 790 & 0,101 \\
5 & Sawah Tadah Hujan & 919 & 0,084 \\
6 & Semak Belukar & 2.337 & 0,105 \\
7 & Tanah Terbuka & 54 & 0,066 \\
8 & Lahan Terbangun & 2.882 & 0,058 \\
& dan Permukiman & & \\
\hline
\end{tabular}

Keragaan vegetasi dapat dilihat juga dari nilai standar deviasi NDVI pada berbagai tutupan lahan (Tabel 5). Nilai standar deviasi NDVI masing-masing tertinggi dan terendah yaitu: perkebunan $(0,113)$ dan lahan terbangun serta permukiman $(0,058)$. Tinggi rendahnya standar deviasi ini menunjukkan keragaman di dalam kelas penggunaan lahan. Pada perkebunan dan kebun terdapat tanaman kopi, teh, karet, cengkeh, lada, dan kakao. Setiap jenis tanaman memiliki bentuk tajuk tanaman dan jarak tanam yang berbeda. Hal ini dapat mempengaruhi gelombang inframerah yang dipantulkan tanaman yang beragam sehingga nilai NDVI menjadi lebih beragam. Lahan terbangun dan permukiman memiliki standar 
deviasi rendah karena vegetasi yang sedikit dan pantulan radiasi NIR lebih rendah sehingga nilai NDVI relatif lebih homogen.

Nilai indeks vegetasi standar deviasi dan kerapatan vegetasi pada berbagai penggunaan lahan di atas menunjukkan bahwa lahan di hulu sub DAS Cikapundung cenderung memiliki kondisi yang tidak tertutup oleh vegetasi secara rapat. Hal ini akan berdampak pada kemampuan lahan untuk menangkap, menahan dan menyerapkan air hujan ke dalam tanah secara optimal. Kondisi tutupan lahan yang ada di lokasi studi cenderung akan berkontribusi pada tingginya aliran permukaan. Hal ini selaras dengan Nurrochman et al. (2018) dan Salim et al. (2019) yang mengemukakan penurunan tutupan lahan vegetasi di hulu DAS berpengaruh pada kondisi hidrologis DAS. Untuk itu perlu upaya peningkatan tutupan lahan seperti melalui reboisasi hutan dan lahan, penghijauan atau pemilihan sistem pertanian yang dapat meningkatkan tutupan lahan vegetasi sehingga fungsi ekologis hulu DAS dapat lebih optimal.

\section{Kesimpulan dan Saran}

Berdasarkan hasil penelitian, maka dapat disimpulkan bahwa:

1. Indeks vegetasi NDVI di Kecamatan Lembang memiliki nilai berkisar antara ($0,228426)$ ahan, Hal i

2. Terdapat karakteristik NDVI yang beragam pada berbagai penggunaan lahan di lokasi studi. Keragaman tertinggi ada pada penggunaan lahan perkebunan dan keragaman terendah pada lahan terbangun dan permukiman. Keragaman ini dipengaruhi oleh jenis vegetasi, sebaran Saran: vegetasi, dan jenis material objek.

Pada kondisi normal di luar masa Pandemi Covid-19, uji akurasi di lapangan perlu dilakukan untuk mengetahui jenis tanaman dan kerapatan tanam yang sama dengan waktu perekaman citra.

\section{Daftar Pustaka}

Arista C.D.N., I.S. Widimulya, K. Rahma, dan Mulyadi. 2017. Analisis Vegetasi Tumbuhan Menggunakan Metode Transek
Garis (Line Transect) di Kawasan Hutan Lindung Lueng Angen Desa Iboih Kecamatan Sukakarya Kota Sabang. Prosiding Seminar Nasional Biotik: 147-151

Dewi, C. dan A.A. Supianto. 2015. Pengolahan Citra Satelit dengan Matlab. Universitas Brawijaya Press.

Dinas Lingkungan Hidup Jawa Barat. 2018. Kondisi Tutupan Lahan Sub DAS Citarum Di Kawasan Bandung Utrara(KBU). http://dlh.jabarprov.go.id /index.php/layanan/k2-categories-2/ item/103-kondisi-tutupan-lahan-sub-dascitarum-di-kawasan-bandung-utara-kbu.

Feng, Y., C. Gao, X. Tong, S. Chen, Z. Lei, and J. Wang. 2019. Spatial Patterns of Land Surface Temperature and Their Influencing Factor : A Case Study in Suzhou, China. Remote Sensing, 11(2): 182

Frananda H. Hartono, dan R. H. Jatmiko. 2015. Komparasi indeks vegetasi untuk estimasi stok karbon hutan mangrove kawasan Segoro Anak pada kawasan taman nasional Alas Purwo Banyuwangi, Jawa Timur. Majalah Ilmiah Globe, 17 (2):113-123

Hidayati I. N., R. Suharyadi, dan P. Danoedoro. 2018. Kombinasi indeks citra untuk analisis lahan terbangun dan vegetasi perkotaan. Majalah Geografi Indonesia, 32 (1): 24-32.

Hogrefe, K.R., V.P. Patil, D.R. Ruthrauff, B.W. Meixell, M.E. Budde, J.W. Hupp, and D.H. Ward. 2017. Normalized Difference Vegetation Index as an Estimator for Abundance and Quality of Avian Herbivore Forage in Arctic Alaska. Remote Sens. 9 (1234): 1-21. doi:10.3390/rs9121234

Irawan S., dan J. Sirait. 2017. Perubahan kerapatan vegetasi menggunakan citra landsat 8 di kota Bata berbasis web. Jurnal Kelautan, 10(2): 174-184

Jaya, I.N.S. 2010. Analisis Citra Digital: Perspektif Penginderaan Jauh Untuk Pengelolaan Sumberdaya Alam. Bogor: Fakultas Kehutanan IPB.

Kinthada N. R., M. K. Gurram, A. Eadara, and V. R. Velagala. 2014. Land use/land cover and NDVI analysis for monitoring the health of micro-watershades of Sarada River Basin, Vinsakhapatnam District, India. Journal of Geology \& Geosciences, 3(2): 1-7

Kurniawan, S., W.O. Nurhaidar, dan I. Salihin. 2017. Optimalisasi transformasi spektral UI, NDBI, NDVI dan kombinasi transformasi spektral UI-NDVI dan NDBI-NDVI guna 
mendeteksi kepadatan lahan terbangun di Kota Magelang. Jurnal Geografi Aplikasi dan Teknologi, 1(1): 13-21

Latuamury, B., T. Gunawan, dan S. Suprayogi. 2012. Pengaruh kerapatan vegetasi penutup lahan terhadap karakteristik resesi hidrograf pada beberapa SubDAS di Provinsi Jawa Tengah dan Provinsi DIY. Majalah Geografi Indonesia, 26(2): 99-116

Lintang N. C., T. B. Sanjoto, dan H. Tjahjono. 2017. Kajian kerapatan vegetasi hutan lindung Gunung Unggaran Jawa Tengah tahun 2016 menggunakan metode indeks vegetasi. Geo Image (1): 1-6

Munawwaroh, A. 2016. Penerapan analisis vegetasi di hutan Mbeji daerah Wonosalam Jombang. Jurnal Pedagogia, 5 (1): 103-110

Navulur, K. 2007. Multispectral Image Analysis Using the Object-Oriented Paradigm. CRC Press.

Nurrochman, E., B. Joy, dan C. Asdak. 2018. Kajian sistem hidrologi akibat perubahan tataguna lahan di kawasan Bandung Utara (studi kasus Kabupaten Bandung Barat). Envirosan, 1(1): 26-28

Peraturan Menteri Kehutanan tentang Perubahan Kedua Atas Peraturan Menteri Kehutanan Nomor P.12/Menhut-II/2012 Tata Cara Penyusunan Rencana Teknik Rehabilitasi Hutan dan Lahan Daerah Aliran Sungai (RTk RHL-DAS). Nomor: P12 Tahun 2010.

Pertiwi A. D.,N. F. A. Safitri, dan D. A. Azzahro. 2019. Penyebaran vegetasi semak, herba, dan pohon dengan metode kuadrat di Taman Pancasila. Proceeding of Biology Education, 3(1): 185-191.

Puntodewo, A., S. Dewi, dan J. Tarigan. 2003. Sistem Informasi Geografi untuk
Pengelolaan Sumber Daya Alam. International Forestry Research (CIFOR). Bogor.

Salim, A.G., I.W.S. Dharmawan, dan B.H. Narendra. 2019. Pengaruh perubahan luas tutupan lahan hutan terhadap karakteristik hidrologi DAS Citarum Hulu. Jurnal Ilmu Lingkungan, 17 (2): 333-340

Sandholt, I., K. Rasmussen, dan J. Andersen. 2002. A simple interpretation of the surface temperature/vegetation index space for assessment of surface moisture status. Remote Sensing of Environment, 79: 213224

Soewarno. 1995. Aplikasi Metode Statistik untuk Analisa Data. Nova. Bandung.

Sudiana, D. dan E Diasmara. 2008. Analisis indeks vegetasi menggunakan data satelit NOAA/AVHRR dan TERRA/AQUAMODIS. Seminar on Intelligent Technology and Its Applications 2008: 423-428

Sutanto. 1986. Penginderaan Jauh Jilid 1. Yogyakarta: Gadjah Mada University Press

Sutrisna, N. , S. R. P. Sitorus, K. Subagyono. 2010. Tingkat kerusakan tanah di hulu Sub DAS Cikapundung kawasan Bandung Utara. Jurnal Tanah Dan Iklim, 32: 71-82

Suwargana, N. 2013. Resolusi spasial, temporal dan spektral pada citra satelit Landsat, SPOT, dan IKONOS. Jurnal Ilmiah WIDYA, 1(2): 167-174

Tucker, C. 1979. Red and photographic infrared linear combination fot monitoring vegetation. Remote Sensing of Environment, 8: 127-150

Zhao, L., P. Zhang, X. Ma, and Z. Pan. 2017. Land cover information extraction based on daily NDVI time series and multiclassifier combination. Hindawi: 1-11. 